RASĀYAN J. Chem.

Vol. 14 | No. 2 |1322-1329| April - June | 2021

ISSN: 0974-1496 | e-ISSN: 0976-0083 | CODEN: RJCABP

http://www.rasayanjournal.com

http://www.rasayanjournal.co.in

\title{
ANNEALING TEMPERATURE AND COCATALYST EFFECTS TO THE PHOTOELECTROCHEMICAL PROPERTY OF CuInS2 THIN FILM SEMICONDUCTOR
}

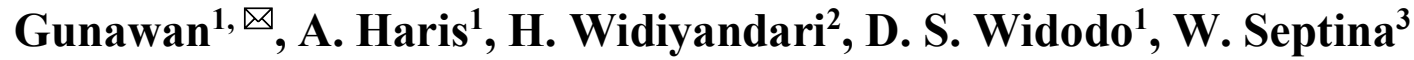 \\ and $S$. Ikeda ${ }^{4}$ \\ ${ }^{1}$ Chemistry Department, Faculty of Science and Mathematics, Diponegoro University, \\ Semarang-50271, Indonesia \\ ${ }^{2}$ Physics Department, Faculty of Mathematics and Natural Sciences, Sebelas Maret University, \\ Surakarta 57126, Indonesia \\ ${ }^{3}$ Hawaii Natural Energy Institute University of Hawai'i at Mānoa (UHM), 1689 East West Road, \\ POST 109 Honolulu, HI 96822, United States \\ ${ }^{4}$ Department of Chemistry, Faculty of Science and Engineering, Konan University, 8-9-1 \\ Okamoto, Higashinada-ku, Kobe 658-8501, Japan \\ ${ }^{\square}$ Corresponding Author: gunawan@live.undip.ac.id
}

\begin{abstract}
Thin film of $\mathrm{CuInS}_{2}$ semiconductor had been synthesized by copper and indium stack electrodepositions on a molybdenum glass substrate and followed by sulfurization at varied annealing temperatures of $600-800{ }^{\circ} \mathrm{C} . \mathrm{CuInS} \mathrm{S}_{2}$ thin film was characterized by using XRD, Raman, and SEM. Then on the CuInS $\mathrm{S}_{2}$ was deposited Pt with various deposition times and its photocurrent property was observed. Finally, Pt or Rh cocatalyst deposited on $\operatorname{In}_{2} \mathrm{~S}_{3}-\mathrm{CuInS} \mathrm{S}_{2}$ was also measured its photoelectrochemical property. XRD, Raman, and SEM data showed CuInS $\mathrm{S}_{2}$ had a different character with varied annealing temperatures. An annealing temperature of $680{ }^{\circ} \mathrm{C}$ gave a maximum photocurrent of $\mathrm{CuInS}_{2}$ as a photocathode. The introduction of cocatalysts increased the photocurrent, even for Rh cocatalyst gave a better-applied bias photon-to-current efficiency than Pt.
\end{abstract}

Keywords: Photocathode, $\mathrm{CuInS}_{2}$, Cocatalyst, Photocurrent.

RASĀYAN J. Chem., Vol. 14, No.2, 2021

\section{INTRODUCTION}

Photoelectrochemical (PEC) water splitting to produce hydrogen gas $\left(\mathrm{H}_{2}\right)$ by using sunlight is hoped to be an ideal and environmentally clean technology to replace fossil fuel sources which tend to reduce in the short years. This idea motivates the scientific community to find various materials and strategies for that purpose. Fujishima et al. as the pioneer of PEC water splitting applied photoanode of $\mathrm{TiO}_{2}$ irradiated by using UV light. ${ }^{1}$ The finding motivated researchers to find out various types of semiconductors and configurations of PEC devices to improve the efficiency of water reduction to produce hydrogen gas $\left(\mathrm{H}_{2}\right)^{2-7}$

Single absorber with a wide bandgap gives a low efficiency of PEC water splitting because it only works at UV light, therefore to improve the efficiency by harvesting all sunlight irradiation regions dual absorbers seem more promising. They consist of photoanode and photocathode electrodes that function as water oxidation and reduction, respectively. With this dual absorber system, researchers can be more flexible and optimal to focus on each electrode, so that it is possible to obtain a real splitting of water without bias by irradiation using sunlight to the absorbers.

Considering the absorber as the cathode part, the materials of Cu-based chacopyrite as a $p$-type semiconductor are promising candidate absorbers for producing $\mathrm{H}_{2}$ evolution efficiently. ${ }^{8-13}$ The compound of $\mathrm{CuInS}_{2}$ is one of the most important chalcopyrite because it has an optimal value of the bandgap and high absorption coefficient, namely $1.5 \mathrm{eV}$ and $10^{4} \mathrm{~cm}^{-1}$, respectively, that allowing it to utilize sunlight efficiently. ${ }^{14}$ Moreover, low-cost electrodeposition and annealing methods of thin-film Rasayan J. Chem., 14(2), 1322-1329(2021) 
RASĀYAN J. Chem.

Vol. 14 | No. 2 |1322-1329| April - June | 2021

fabrication techniques enable to prepare $\mathrm{CuInS}_{2}$ photoelectrodes with high structural and optical quality. ${ }^{15-18}$ Surface modification of $\mathrm{CuInS}_{2}$ using buffer layer of $n$-type and platinum introduction enhances the cathodic photocurrent and it is very important for a better separation of electrons and holes generated by illumination. ${ }^{19}$ Platinum is the best cocatalyst until now to perform hydrogen evolution reaction by facilitating interfacial charge transfer reactions ${ }^{20}$. Meanwhile, for water reduction, the semiconductor surfaces as electrodes have no especially catalytic property due to their high photogenerated carrier recombination. As it is usually applied widely in solar cells by fabrication $p$ and $n$ types of semiconductors of Cu-based chalcopyrite ( $p$ - $n$ junctions) the covering of $n$-type of buffer layer on photo absorbers increases the photocurrent of the photocathode. ${ }^{21-24}$ In this study, we investigated the effect of annealing temperatures of $\mathrm{CuInS}_{2}$ thin film, and insertion of cocatalyst of $\mathrm{Pt}$ or $\mathrm{Rh}$ on the surface of photocathode of $\operatorname{In}_{2} \mathrm{~S}_{3}$ covered $\mathrm{CuInS}_{2}$ to improve its photoelectrochemical property since limited previous works discussed these cases. Their works mainly correlated to the temperature annealing effect of $\mathrm{CuInS}_{2}$ on the structural and morphological as well as optical properties. ${ }^{25,26}$

\section{Materials and Instrumentations}

\section{EXPERIMENTAL}

The chemicals used were $\mathrm{CuSO}_{4}, \mathrm{InCl}_{3}$, trisodium citrate, citric acid, acetone, $\mathrm{KCN}, \mathrm{In}_{2}\left(\mathrm{SO}_{4}\right)_{3}$, thioacetamide, $\mathrm{CH} 3 \mathrm{COOH}, \mathrm{H}_{2} \mathrm{PtCl}_{6}, \mathrm{RhCl}_{3}, \mathrm{Na}_{2} \mathrm{SO}_{4}, \mathrm{Eu}\left(\mathrm{NO}_{3}\right)_{3}, \mathrm{NaH}_{2} \mathrm{PO}_{4}$. All chemicals were bought from Merck and used without purification. Molybdenum glasses were purchased from Geomatec Ltd. Japan. For annealing and drying the $\mathrm{Cu} / \mathrm{In}$ film used $\mathrm{H}_{2} \mathrm{~S}(5 \%)$ and $\mathrm{N}_{2}$ gases, respectively.

Potentiostat (Hokuto Dento 110) was used for electrodeposition of copper, indium, platinum and rhodium. X-ray diffraction (XRD) was performed for analysis of crystalline structures of the $\mathrm{CuInS}_{2}$ film using PANalytical X Pert ${ }^{3}$ Powder X-ray diffractometer $\left(\mathrm{Cu} \mathrm{K \alpha}\right.$, Ni filter). The $\mathrm{CuInS}_{2}$ thin film's morphology was analyzed by using a scanning electron microscope (SEM) JSM-6510LA Analytical at an acceleration voltage of $20 \mathrm{kV}$. Raman analyses were obtained by using Raman Spectrophotometer (Jasco NRC 3100 Laser) with an excitation laser at a wavelength of $532 \mathrm{~nm}$. Photocurrent responses and PEC measurements of bare and modified $\mathrm{CuInS}_{2}$ used potentiostat coupled with digital function generator at $0.3 \mathrm{~Hz}$ and Shutter Controller.

\section{Electrodeposition of $\mathrm{Cu} / \mathrm{In}$ on Molybdenum Glass}

The electrodeposition was carried out from copper then continued with indium electrolyte solutions successively with $\mathrm{Ag} / \mathrm{AgCl}, \mathrm{Pt}-$ wire, and a Mo-covered glass substrate $(0.7 \mathrm{~cm} \times 1.0 \mathrm{~cm})$ as a reference, counter and working electrodes, respectively. Copper electrolyte $\mathrm{pH} 2.38$ contained $0.05 \mathrm{M} \mathrm{CuSO}_{4}, 0.15 \mathrm{M}$ trisodium citrate, and $0.242 \mathrm{M}$ citric acid. While indium electrolyte contained $0.03 \mathrm{M} \mathrm{InCl}_{3}, 0.242 \mathrm{M}$ citric acid, and $0.036 \mathrm{M}$ trisodium citrate. The electrodepositions were run for 7 and 15 min for copper and indium using potentiostat at potentials of -0.2 and $-0.78 \mathrm{~V}$, respectively.

\section{Effect of Annealing Temperature of $\mathrm{CuInS}_{2}$}

As deposited $\mathrm{Cu}$-In was converted to $\mathrm{CuInS}_{2}$ by pre-annealing for $30 \mathrm{~min}$ at a temperature of $160{ }^{\circ} \mathrm{C}$ in $\mathrm{Ar}$ gas with flow rate at $200 \mathrm{~mL} / \mathrm{min}$ and annealing for 10 min under $200 \mathrm{~mL} / \mathrm{min}$ of $\mathrm{H}_{2} \mathrm{~S}\left(5 \% \mathrm{H}_{2} \mathrm{~S}\right)$ flow in a glass tube furnace. The annealing temperature was varied at a temperature from 600 until $800{ }^{\circ} \mathrm{C}$. Then the $\mathrm{CuInS}_{2}$ was immersed in $\mathrm{KCN}(10 \%)$ for 2 min to remove excess of $\mathrm{Cu}_{\mathrm{x}} \mathrm{S}$. Effect of annealing temperature of $\mathrm{CuInS}_{2}$ was observed by photocurrent response measurements used potentiostat coupled with digital function generator at $0.3 \mathrm{~Hz}$ and Shutter Controller. Three electrodes containing $\mathrm{Ag} / \mathrm{AgCl}$ electrode, Pt counter electrode and $\mathrm{CuInS}_{2}$ as working electrode were immersed in $0.2 \mathrm{M} \mathrm{Eu}\left(\mathrm{NO}_{3}\right)_{3}$ solution. The measurement was run by chopped 1.5 AM light radiation to the working electrode with a sweep potential from 0 until $-0.45 \mathrm{~V}$ and a scan rate of $10 \mathrm{mV} / \mathrm{s}$. Analysis of Raman, XRD and SEM were applied to characterize the effect of varying temperatures on synthesized $\mathrm{CuInS}_{2}$.

\section{Effect of Pt Cocatalyst Deposition}

Pt electrodeposition on bare-CuInS $\mathrm{S}_{2}$ films was done using $20 \mathrm{~mL}$ electrolyte consisting $1 \mathrm{mM} \mathrm{H}_{2} \mathrm{PtCl}_{6}$ and $0.1 \mathrm{M} \mathrm{Na} \mathrm{SO}_{4}$ in cylindric flask with a window. Then into the flask was inserted bare-CuInS 2 
RASĀYAN J. Chem.

Vol. 14 | No. 2 |1322-1329| April - June | 2021

photocathode, $\mathrm{Pt}$, and $\mathrm{Ag} / \mathrm{AgCl}$ as working, counter, and reference electrodes, respectively. Pt was photoelectrodeposited on the working electrode at various deposition times using potentiostat under illumination. Photocurrent response was measured using a similar procedure as above.

\section{Effect of Type of Cocatalysts}

Before deposition of cocatalysts, bare-CuInS$S_{2}$ film was covered with $\operatorname{In}_{2} \mathrm{~S}_{3}$ by immersed in an electrolyte containing $0.025 \mathrm{M}$ indium sulfate, $100 \mathrm{mM}$ thiacetamide and $100 \mathrm{mM}$ acetic acid at $65^{\circ} \mathrm{C}$ for $15 \mathrm{~min}$. Then $\mathrm{Pt}$ or $\mathrm{Rh}$ was deposited on modified $\mathrm{CuInS}_{2}$ with a similar procedure as above with concentration $1 \mathrm{mM}$ for $10 \mathrm{~s}$. Photoelectrochemical properties were performed in $0.2 \mathrm{M} \mathrm{NaH}_{2} \mathrm{PO}_{4}$ solution using a similar instrument and parameter as photocurrent response measurement. APBE (applied bias photon-tocurrent efficiency) was evaluated using equation:

$$
\operatorname{ABPE}(\%)=\mathrm{J} \times \mathrm{V}_{\mathrm{b}} \times 100 / \mathrm{P}_{\mathrm{AM} 1.5}
$$

Where $J$ is photocurrent $\left(\mathrm{mA} / \mathrm{cm}^{2}\right), V_{b}$ is bias voltage (RHE scale), and $P_{A M 1.5}$ is $1.5 A M$ simulated radiation $\left(100 \mathrm{~mW} / \mathrm{cm}^{2}\right)$. While RHE is calculated as the following, $\mathrm{RHE}=\mathrm{E}_{\mathrm{Ag} / \mathrm{AgCl}}+0.059 \mathrm{xpH}+0.199$.

\section{Effect of Annealing Temperature of $\mathrm{CuInS}_{2}$}

RESULTS AND DISCUSSION

Preparation of semiconductors of $\mathrm{CuInS}_{2}$ by successive electrodeposition of $\mathrm{Cu}$ and $\mathrm{In}$ of the precursor was conducted by annealing as-deposited $\mathrm{Cu} / \mathrm{In}$ in $\mathrm{H}_{2} \mathrm{~S}$ gas at a temperature of 600 until $800{ }^{\circ} \mathrm{C}$. The obtained $\mathrm{CuInS}_{2}$ then were examined their photocurrent responses in $0.2 \mathrm{M}$ europium solution (as electron scavenging) with chopped illumination and the results are depicted in Fig.-1. The figure can be seen the maximum photocurrent around $12.2 \mathrm{~mA} / \mathrm{cm}^{2}$ at a potential of $-0.4 \mathrm{~V}$ for $\mathrm{CuInS}_{2}$ annealed at $680{ }^{\circ} \mathrm{C}$ with a good dark current. There is an anomaly in the results of the photocurrent response at temperatures of 620 and $640{ }^{\circ} \mathrm{C}$. However, the photocurrent response has a trend to be optimum at $680{ }^{\circ} \mathrm{C}$ and becomes decrease after that temperature; those are 5.8 and $5.2 \mathrm{~mA} / \mathrm{cm}^{2}$ at annealing temperatures of 750 and $800^{\circ} \mathrm{C}$, respectively (Tabel-1). $\mathrm{CuInS}_{2}$ annealed at 700 to $800^{\circ} \mathrm{C}$ gave a bad dark current, since the dark current not flat. The good absorber semiconductor should have zero current when there is no light (at dark).

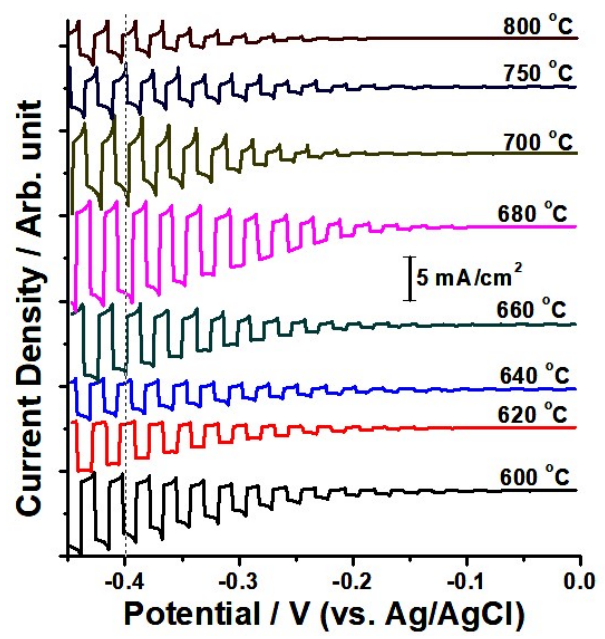

Fig.-1: Current-potential Curves of $\mathrm{CuInS}_{2}$ measured using Potentiostat in Europium Solution under Chopped 1.5AM Simulated Radiation using Three-electrode systems.

Tabel-1: Photocurrent Response of $\mathrm{CuInS}_{2}$ after Annealing at Varied Temperatures

\begin{tabular}{c|c|c|c|c|c|c|c|c}
\hline Annealing Temperature $\left({ }^{\circ} \mathrm{C}\right)$ & 600 & 620 & 640 & 660 & 680 & 700 & 750 & 800 \\
\hline $\begin{array}{c}\text { Photocurrent at Potential of -0.4 V } \\
(v s . \mathrm{Ag} / \mathrm{AgCl})\left(\mathrm{mA} / \mathrm{cm}^{2}\right)\end{array}$ & -8.1 & -5.0 & -3.8 & -7.9 & -12.2 & -9.7 & -5.8 & -5.2 \\
\hline
\end{tabular}


RASĀYAN J. Chem.

Vol. 14 | No. 2 |1322-1329| April - June | 2021

Figure-2 shows are typical $\mathrm{CuInS}_{2}$ spectra at different annealing temperatures using Raman spectrophotometer. Raman shift at ca. $300 \mathrm{~cm}^{-1}$ is a typical peak for $\mathrm{CuInS}_{2}$ and no other peaks appear for annealing temperatures until $680{ }^{\circ} \mathrm{C}$. Whilst at annealing temperatures of 700 until $800{ }^{\circ} \mathrm{C}$ beside the peak of $\mathrm{CuInS}_{2}$, there are other peaks of molybdenum element coming from molybdenum glass substrate used because the molybdenum was evaporated and deposited at the surface of $\mathrm{CuInS}_{2}$ thin film when subjected to the temperatures. Therefore, it covered the surface of $\mathrm{CuInS}_{2}$ confirmed by the low-intensity peaks of $\mathrm{CuInS}_{2}$ thin films annealed at temperatures of $700,750,800{ }^{\circ} \mathrm{C}$. The molybdenum has Raman shifts ca.321.8, 407.4, $453.4 \mathrm{~cm}^{-1}$.

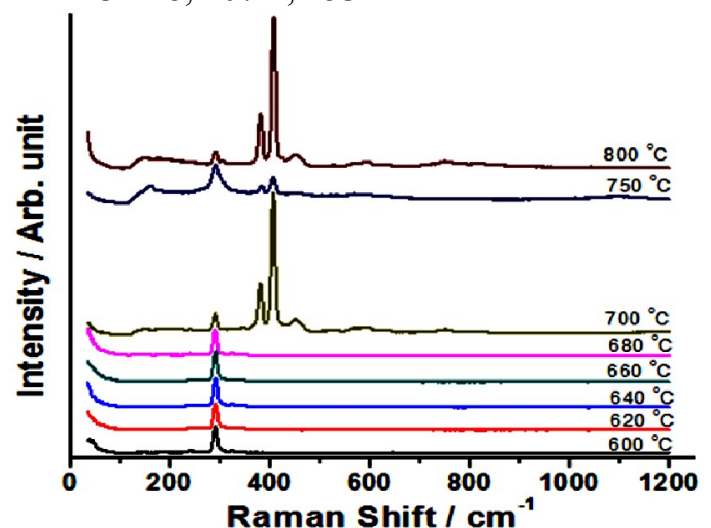

Fig.-2: $\mathrm{CuInS}_{2}$ Raman Spectra annealed at Various Temperatures

The XRD spectra of $\mathrm{CuInS}_{2}$ obtained from various annealing temperatures are shown in Fig.-3. The figure shows that at $2 \theta$ of $40.8^{\circ}$ is the peak from molybdenum. While diffraction peaks at ca. $28.2,46.8$, and $55.4^{\circ}$ are corresponding to the main crystalline chalcopyrite $\mathrm{CuInS}_{2}$ phase. The values are almost close to the work of Bini et al. ${ }^{27}$

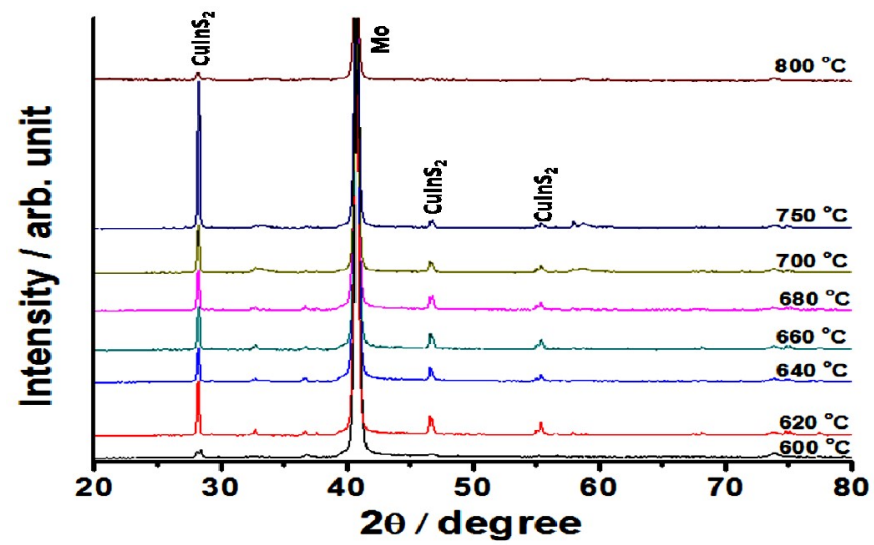

Fig.-3: XRD of $\mathrm{CuInS}_{2}$ Obtained from Different Annealing Temperatures

Thin-film of $\mathrm{CuInS}_{2}$ grain size was evaluated using formula of Debye-Scherrer, namely, $\mathrm{D}=0.9 \lambda / \beta$ $\cos \theta$. The values of $\mathrm{D}, \lambda, \beta$, and $\theta$ are the diameter of the crystallites forming the film, wavelength of the $\mathrm{CuK} \alpha$ line, FWHM and Bragg angle, respectively. The average grain sizes obtained from all peaks of $\mathrm{CuInS}_{2}$ are in the range of 23 and $38 \mathrm{~nm}$ (Fig.-4). As the temperature increases, the grain size improves until temperature $640{ }^{\circ} \mathrm{C}$ with the highest grain size of $38.36 \mathrm{~nm}$ and after that, the grain size becomes decreases to $32.48 \mathrm{~nm}$. As it is seen from Raman curve at higher annealing temperature $\left(>700{ }^{\circ} \mathrm{C}\right)$ was not merely $\mathrm{CuInS}_{2}$ present in the thin film. Since the $\mathrm{CuInS}_{2}$ thin films prepared is almost pure, increasing temperature is effective until $640{ }^{\circ} \mathrm{C}$, this is also confirmed by previous research that showed annealing temperature of $\mathrm{CuInS}_{2}$ until the temperature of $550^{\circ} \mathrm{C} .{ }^{28}$

Figure-5 shows SEM of a thin film of $\mathrm{CuInS}_{2}$ annealed at the temperatures of 600,640 , and $750{ }^{\circ} \mathrm{C}$ as a representation for three areas that have different grain sizes as shown in Fig.-4. The SEM shows that for $\mathrm{CuInS}_{2}$ annealed at $600{ }^{\circ} \mathrm{C}$ has a porous property and small grain size, meanwhile the $\mathrm{CuInS}_{2}$ annealed at 
RASĀYAN J. Chem.

Vol. 14 | No. 2 |1322-1329| April - June | 2021

$640{ }^{\circ} \mathrm{C}$ has a bigger grain size and also it looks like the film became melt. Although the decrease of grain size did not appear at an annealing temperature of $750{ }^{\circ} \mathrm{C}$, the melted-like was disappeared. This can be due to the presence of molybdenum covered on its surface as confirmed by Raman measurement.

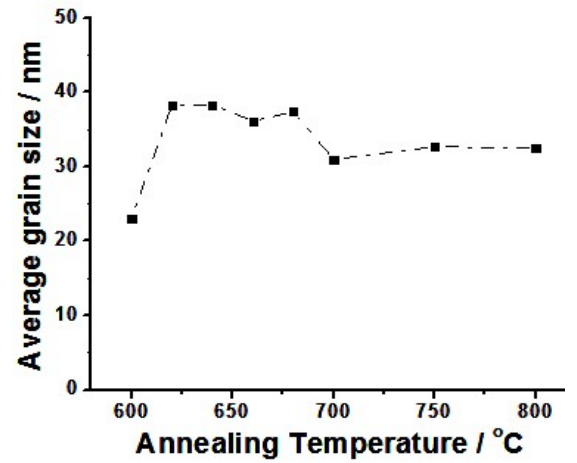

Fig.-4: Average Grain Size of a Thin Film of $\mathrm{CuInS}_{2}$ at Various Annealing Temperatures

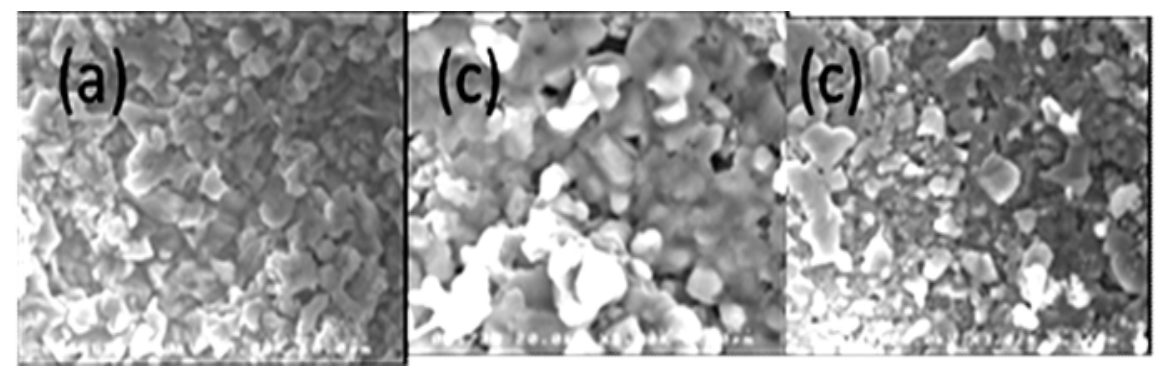

Fig.-5: SEM of $\mathrm{CuInS}_{2}$ Annealed at Temperatures of 600,640 , and $750{ }^{\circ} \mathrm{C}$

\section{Effect of Pt cocatalyst Deposition}

Platinum is a cocatalyst for hydrogen evolution reaction since it can bind with hydrogen ion to form ideal bond strength of $\mathrm{Pt}-\mathrm{H}$ that can facilitate adsorption process and reduction of hydrogen ion and to release $\mathrm{H}_{2}$ easily when reduction process is complete. ${ }^{20}$ Figure- 6 shows the deposition of Pt improves the photocurrent and onset potential compared with bare-CuInS ${ }_{2}$. The photocurrent increases from 1.5 to 5 $\mathrm{mA} / \mathrm{cm}^{2}$ for bare and Pt deposited $\mathrm{CuInS}_{2}$, respectively. While the onset potential gave more positive potential for Pt deposited $\mathrm{CuInS}_{2}$ than bare-CuInS 2 . However, the increase of deposition times (from $20 \mathrm{~s}$ until $1 \mathrm{~h}$ ) has no significant effect on photocurrent as well as onset potential of Pt-CuInS $\mathrm{S}_{2}$.

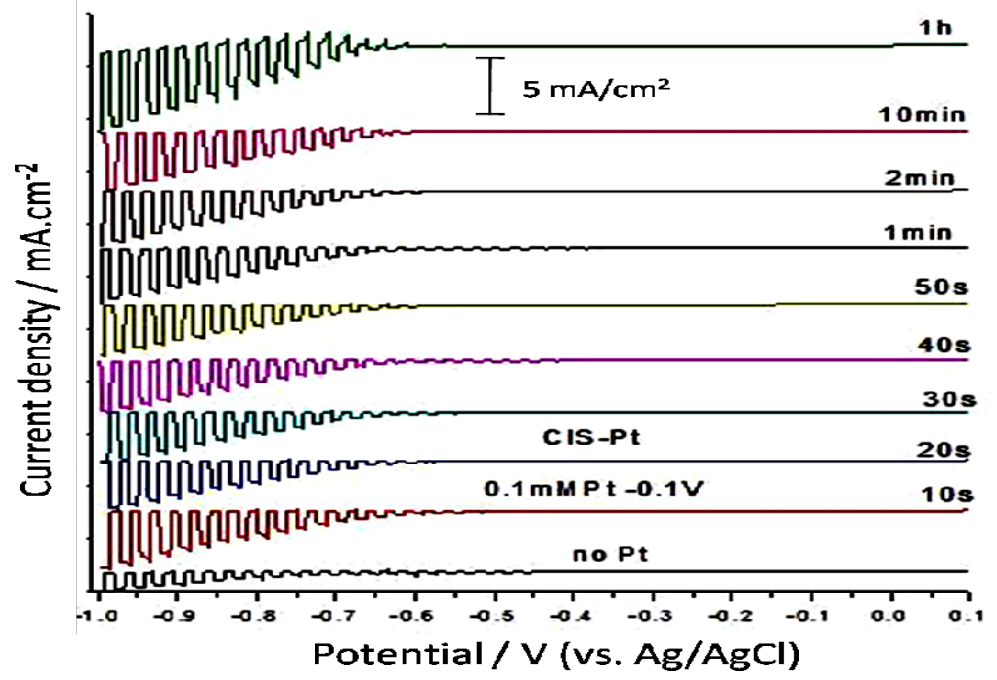

Fig.-6: Effect of Platinum Deposition Times on $\mathrm{CuInS}_{2}$ to the Curves of Current-potential of Pt-CuInS $\mathrm{Photocathode}_{2}$ measured in $0.1 \mathrm{M} \mathrm{Na}_{2} \mathrm{SO}_{4}$ at $\mathrm{pH} 9$ under Chopped 1.5AM Simulated Radiation 
RASĀYAN J. Chem.

Vol. 14 | No. 2 |1322-1329| April - June | 2021

\section{Effect of Type of Cocatalyst}

Effect of type of cocatalyst was evaluated using Rh as replacement of Pt. Since Pt has a work function a relatively large ca. $5.65 \mathrm{eV},{ }^{29}$ the formation of Schottky-type potential barrier would be possible that resists the transfer of electron. Therefore, $\mathrm{Pt}$ can be replaced by $\mathrm{Rh}$ as a candidate to reduce the potential barrier because of its relatively small work function $(4.98 \mathrm{eV}),{ }^{29}$ possible depositions by a photoelectron chemical method similar to that employed for the platinum deposition, and relatively low overpotential for water reduction comparable to that of $\mathrm{Pt}^{30,31}$ Figure-7a shows typical current and potential scans of $\mathrm{Pt}$ and $\mathrm{Rh}$ covered $\mathrm{In}_{2} \mathrm{~S}_{3} / \mathrm{CuInS}_{2}$ electrodes, respectively. The result shows appreciable improvement of photocurrent and also the onset potential achieved by using Rh catalyst for the $\mathrm{In}_{2} \mathrm{~S}_{3} / \mathrm{CuInS}_{2}$ electrode and improving the ABPE more than $2 \%$ for Rh catalyst, as shown in Fig.-7b. Since there is no significant improvement when the $\mathrm{Rh}$ catalyst was used instead of the $\mathrm{Pt}$ catalyst for the $\mathrm{CdS} / \mathrm{CuInS}_{2}$ electrode system, the use of $\mathrm{Rh}$ should work well by a combination with $\mathrm{In}_{2} \mathrm{~S}_{3}$ but not for CdS having a relatively negative conduction band minimum (CBM). ${ }^{32}$ Figure- 8 shows the energy diagram of $\operatorname{In}_{2} \mathrm{~S}_{3} / \mathrm{CuInS}_{2}$, Rh and Pt. The absolute and the electrochemical scales are given on the right side.

(a)

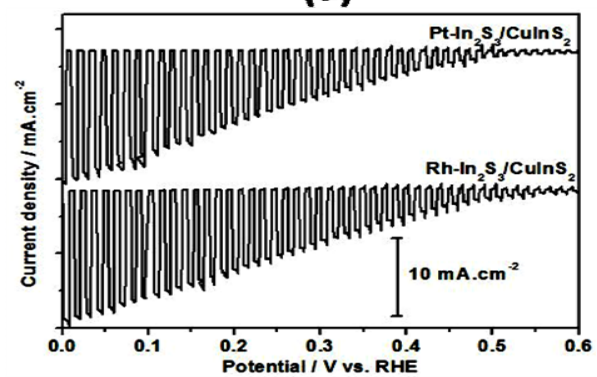

(b)

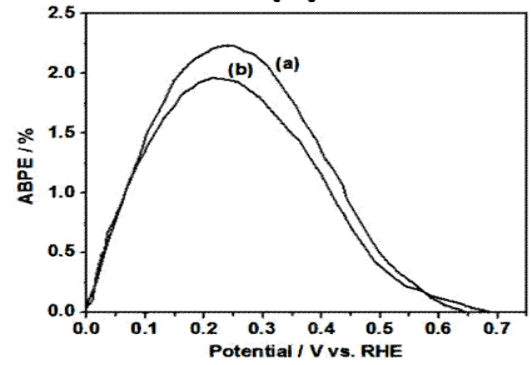

Fig.-7: (a) Current-potential Curves of Pt and Rh covered $\operatorname{In}_{2} \mathrm{~S}_{3} / \mathrm{CuInS}_{2}$ Photocathodes, respectively, in a Solution of $0.2 \mathrm{M} \mathrm{NaH}_{2} \mathrm{PO}_{4}$ at $\mathrm{pH} 6$ with Chopped AM 1.5 Simulated Irradiation. (b) ABPE of Pt and Rh covered $\operatorname{In}_{2} \mathrm{~S}_{3} / \mathrm{CuInS}_{2}$ Photocathode, respectively.

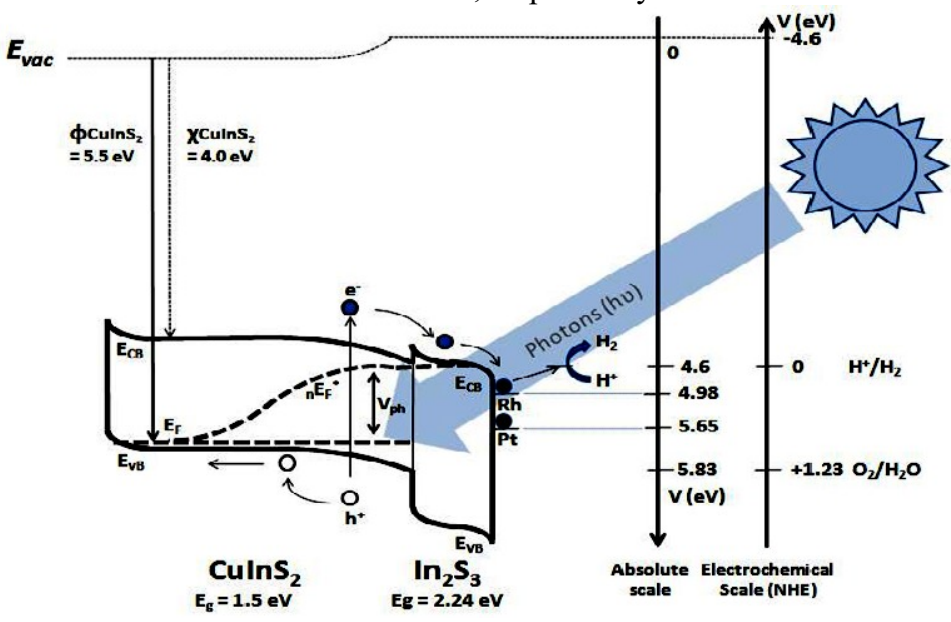

Fig.-8: Energy Diagram of $\operatorname{In}_{2} \mathrm{~S}_{3} / \mathrm{CuInS}_{2}$, Rh and Pt. The Absolute and the Electrochemical Scales are given on the Right Side.

\section{CONCLUSION}

$\mathrm{CuInS}_{2}$ thin film had an optimum photocurrent response value of $12.2 \mathrm{~mA} / \mathrm{cm}^{2}$ when it was annealed at $680^{\circ} \mathrm{C}$. Deposition of platinum on $\mathrm{CuInS}_{2}$ improved the photocurrent compared to bare $\mathrm{CuInS}_{2}$. However, increasing times of Pt depositions had no significant effect on photoelectrochemical properties of the Pt$\mathrm{CuInS}_{2}$ photocathodes. Due to the relatively high CBM of the $\operatorname{In}_{2} \mathrm{~S}_{3}$ photocathode layer, direct deposition of conventional Pt catalysts was found to be not optimal due to the generation of a large Schottky barrier; instead, the use of Rh was beneficial for this system, though it is still not sufficiently improved. 
RASĀYAN J. Chem.

Vol. 14 | No. 2 |1322-1329| April - June | 2021

\section{ACKNOWLEDGEMENT}

Financial grant from Diponegoro University (Selain APBN DPA SUKPA LPPM Universitas DiponegoroRPI-2, 2018) was acknowledged.

\section{REFERENCES}

1. A. Fujishima and K. Honda, Nature, 238(5358),37(1972), DOI:10.1038/238037a0

2. Z. Liu, J. Zhang and W. Yan, ACS Sustainable Chemistry and Engineering, 6(3), 3565(2018), DOI: $10.1021 /$ acssuschemeng.7b03894

3. J. Li, X. Jin, R. Li, Y. Zhao, X. Wang, X. Liu and H. Jiao, Applied Catalysis B: Environmental, 240, 1(2019), DOI:10.1016/j.apcatb.2018.08.070

4. C. Liu, F. Wang, J. Zhang, K. Wang, Y. Qiu, Q. Liang and Z. Chen, Nano-Micro Letters, 10(2), 37(2018), DOI:10.1007/s40820-018-0192-6

5. S. Zhou, K. Chen, J. Huang, L. Wang, M. Zhang, B. Bai, H. Liu and Q. Wang, Applied Catalysis B: Environmental, 266, 118513(2020), DOI:10.1016/j.apcatb.2019.118513

6. H. Wu, Z. Zheng, C. Y. Toe, X. Wen, J. N. Hart, R. Amal and Y. H. Ng, Journal of Materials Chemistry A, 8, 5638(2020), DOI:10.1039/d0ta00629g

7. M. P. D. Parimala, M. S. Kumar and M.C. Rao, Rasayan Journal of Chemistry, 10(3), 825(2017), DOI: $10.7324 /$ RJC.2017.1031746

8. Q. Cai, Z. Liu, C. Han, Z. Tong and C. Ma, Journal of Alloys and Compounds, 795, 319(2019), DOI:10.1016/j.jallcom.2019.04.312

9. D. Chen, Z. Liu, Z. Guo, W. Yan and M. Ruan, Chemical Engineering Journal, 381, 122655(2020), DOI: $10.1016 /$ j.cej.2019.122655

10. N. Gaillard, D. Prasher, M. Chong, A. D. DeAngelis, K. Horsley, H. A. Ishii, J. P. Bradley, J. Varley and T. Ogitsu, ACS Applied Energy Materials, 2, 5515(2019), DOI:10.1021/acsaem.9b00690

11. P. Endla, Rasayan Journal of Chemistry, 12(4), 1676(2019), DOI:10.31788/RJC.2019.1245132

12. Z. Liu, X. Lu and D. Chen, ACS Sustainable Chemistry and Engineering, 6(8), 10289(2018), DOI: 10.1021/acssuschemeng.8b01607

13. V. Prasad, G. G. Simiyon, A. E. Mammen and N. Jayaprakash, Rasayan Journal of Chemistry, 12(2), 860(2019), DOI:10.31788/RJC.2019.1225226

14. M. A. Green, K. Emery, D. L. King, S. Igari and W. Warta, Progress in Photovoltaics: Research and Applications, 10(4),355(2002), DOI:10.1002/pip.453

15. M. Esmaeili-Zare and M. Behpour, International Journal of Hydrogen Energy, 45(32), 16169(2020), DOI:10.1016/j.ijhydene.2020.04.106

16. K. Matoba, Y. Matsuda, M. Takahashi, Y. Sakata, J. Zhang and S. Higashimoto, Catalysis Today, In Press (2020), DOI:10.1016/j.cattod.2020.01.015

17. C. An, F. Liu and J. Yuan, Composite Interfaces, 1-14(2020), DOI: $10.1080 / 09276440.2020 .1855572$

18. S. Saber, M. Mollar, M., A. El Nahrawy, N. Khattab, A. Eid, M. Abo-Aly and B. Mari, Optical Quantum Electronics, 50(6), 248(2018), DOI:10.1007/s11082-018-1521-1

19. B. Kim, K. Kim, Y. Kwon, W. Lee, W. H. Shin, S. Kim and J. Bang, ACS Applied Nano Materials, 1(6), 2449(2018), DOI:10.1021/acsanm.8b00250

20. Q. Cai, Z. Liu, C. Ma, Z. Tong and C. Han, Journal of Materials Science: Materials in Electronics, 29, 20629(2018), DOI:10.1007/s10854-018-0201-Z

21. Z. Chen, X. Liu, Y. Zhao, X. Liang, Y. Chen, L. Wang and Y. Shen, Journal of Sol-Gel Science and Technology, 85(1), 12(2018), DOI:10.1007/s10971-017-4525-6

22. Y. Tani, K. Imada, T. Kamimura, M. Takahashi, M. Anpo and S. Higashimoto, Research on Chemical Intermediates, 47, 169(2021), DOI:10.1007/s11164-020-04349-8

23. M. Li, R. Zhao, Y. Su, J. Hu, Z. Yang and Y. Zhang, Applied Catalysis B: Environmental, 203, 715(2017), DOI:10.1016/j.apcatb.2016.10.051

24. T. Tomai, Y. Yasui, S. Watanabe, Y. Nakayasu, L. Sang, M. Sumiya, T. Momose and I. Honma, The Journal of Supercritical Fluids, 120, 448(2017), DOI:10.1016/j.supflu.2016.05.026 
RASĀYAN J. Chem.

Vol. 14 | No. 2 |1322-1329| April - June | 2021

25. P. Dube, A. O. Juma and C. M. Muiva, Ceramics International, 46(6), 7396(2019), DOI: $10.1016 /$ j.ceramint.2019.11.235

26. J. P. Sawant, R. J. Deokate, H. M. Pathan and R. B. Kale, Engineered Science, 13, 51(2021), DOI: $10.30919 / \mathrm{es} 8 \mathrm{~d} 1147$

27. S. Bini, K. Bindu, M. Lakshmi, C. S. Kartha, K. Vijayakumar, Y. Kashiwaba and T. Abe, Renewable Energy, 20(4), 405(2000), DOI:10.1016/S0960-1481(99)00122-6

28. R. Brini, M. Kanzari, B. Rezig and J. Werckmann, European Physical Journal Applied Physics, 30(3), 153(2005), DOI:10.1051/epjap:2005031

29. S. Wei, and A. Zunger, Applied Physics Letters, 63(18), 2549(1993), DOI:10.1063/1.110429

30. A. Niemegeers, M. Burgelman and A. De Vos, Applied Physics Letters, 67(6), 843(1995), DOI: $10.1063 / 1.115523$

31. Y. Hashimoto, K. Takeuchi, and K. Ito, Applied Physics Letters, 67(7), 980(1995), DOI: $10.1063 / 1.114965$

32. Gunawan, W. Septina, T. Harada, Y. Nose, and S. Ikeda, ACS Applied Materials and Interfaces, 7(29), 16086(2015), DOI:10.1021/acsami.5b04634

[RJC-5918/2020] 